\title{
Current management of radiation cystitis: A review and practical guide to
}

\section{clinical management}

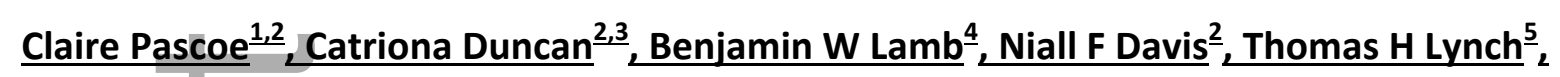
Declan G Murphy ${ }^{\underline{1}}$, Nathan Lawrentschuk ${ }^{1,2}$

1. Department of Cancer Surgery, Peter MaCallum Cancer Centre, Melbourne, Australia

2. Department of Urology, Austin Health Heidelberg, Australia

3. North Eastern Urology, Heidelberg, Australia

4. Department of Urology, Cambridge University Hospitals NHS Foundation Trust, Cambridge, United Kingdom.

5. Department of Urology, St James Hospital, Dublin 8, Ireland.

Corresponding Author -

A/Prof Nathan Lawrentschuk

E: lawrentschuk@gmail.com

M: +61 488088240

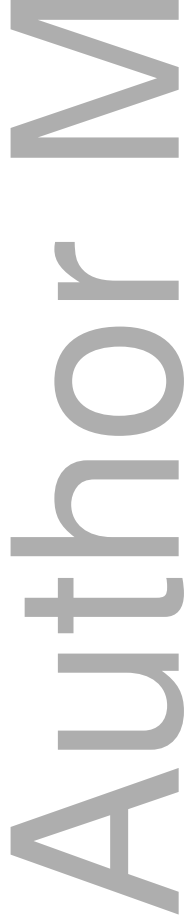

This is the author manuscript accepted for publication and has undergone full peer review but has not been through the copyediting, typesetting, pagination and proofreading process, which may lead to differences between this version and the Version of Record. Please cite this article as doi: $10.1111 /$ bju.14516

This article is protected by copyright. All rights reserved 
MR. NIALL F DAVIS (Orcid ID : 0000-0002-5298-1475)

DR. DECLAN MURPHY (Orcid ID : 0000-0002-7500-5899)

DR. NATHAN LAWRENTSCHUK (Orcid ID : 0000-0001-8553-5618)

Article type : Review

Keywords: radiation, radiotherapy, cystitis, management, haemorrhage, bleeding, bladder

\begin{tabular}{ll}
\hline Abbreviation & Term \\
\hline ATMs & atmospheres \\
\hline BPH & Benign prostatic hypertrophy \\
CR & Continuous bladder irrigation \\
GAG & Complete response \\
HBO(T) & glycosaminoglycan \\
IMRT & Hyperbaric oxygen (therapy) \\
NKTCs & Image modulated radiation therapy \\
NR & Natural killer cells \\
PR & Not recorded \\
\hline QoL & Partial response \\
\hline SPP & Quality of Life \\
TCDO & Sodium pentosan polysulphate \\
\hline TF & tetrachlorodecaoxygen \\
YAG & Treatment failure \\
\hline
\end{tabular}

\section{Abstract}

This article is protected by copyright. All rights reserved 
Haemorrhage is a frequent complication of radiation cystitis leading to emergency presentations in patients with prior pelvic radiation therapy. Standard initial patient management strategies involve resuscitation, bladder washout with clot evacuation and continuous bladder irrigation. Beyond this, definitive surgical treatment is associated with significant morbidity and mortality. Alternative less invasive management options for nonemergent haemorrhagic cystitis include systemic medical therapies, hyperbaric oxygen, intra-vesical therapies and laser ablation. However, evidence to support and compare treatment for haemorrhagic radiation cystitis is limited. Herein, a literature search pertaining to the current management of haemorrhagic cystitis was conducted. With evaluation of existing literature, this narrative review also provides a stepwise clinical algorithm to aid the urologist in treating patients presenting with complications associated with radiation cystitis.

\subsection{Introduction}

Chronic haemorrhagic cystitis occurs up to $5 \%$ of patients following pelvic radiotherapy [1]. Although the advent of intensity modulated radiation therapy (IMRT) may decrease radiation induced bladder toxicity; robust data on long-term outcomes are limited [2]. The response of the urinary bladder to radiation treatment can be classified into acute or subacute reactions that typically occur within 3-6 months of radiation treatment and late reactions that occur after six months. Delayed radiation induced endothelial cell damage and perivascular fibrosis result in ischaemia and obliterative end arteritis leading to a range of symptoms including urinary frequency, urgency, pelvic pain and haematuria[3].

Complications associated with radiotherapy account for up to $7 \%$ of emergency urology admissions [4]. Initial management of radiation cystitis with haemorrhage frequently involves a sequential algorithm consisting of initial resuscitation and reversal of anticoagulation as clinically appropriate, copious bladder washouts with clot evacuation, followed by continuous bladder irrigation (CBI) and blood transfusions as required. Characteristic cystoscopy findings are telangiectasia with friable erythematous mucosa [5]. Intractable haemorrhagic cystitis severely impacts on a patient's quality of life (QoL) with 
persistent bleeding resulting in life threatening hypovolaemic shock [6]. The management of complex patients on anticoagulation requires balanced clinical decisions regarding the risks and benefits of blood transfusions and cessation of anticoagulation by the treating physician, however often short periods without anticoagulation may be required to interrupt the pathological cycle. Urinary diversion and cystectomy for end-stage haemorrhagic cystitis is associated with a $44 \%$ mortality rate $[7,8]$. Alternative less invasive management options for non-emergent haemorrhagic cystitis include systemic medical therapies, hyperbaric oxygen, intravesical therapies and laser ablation. These treatment strategies have several limitations including difficulty obtaining and administering some of the more historical treatments, such as formalin and alum, in the contemporary clinical setting. There is also a dearth of level one evidence for the efficacy of such treatments. A further limitation is the absence of a pre-determined management algorithm regarding best clinical practice for patients presenting with symptomatic radiation induced haemorrhagic cystitis. In this narrative review, we summarise available therapies for treating chronic radiation induced hemorrhagic cystitis and propose a practical management algorithm.

\section{$2.0 \quad$ Methods}

A literature search was undertaken using Medline, Embase, Pub Med and Google Scholar. The following terms were entered into the search algorithm to identify peer-reviewed articles that investigated management strategies for radiation induced hemorrhagic cystitis: "radiation or radiotherapy", "cystitis", "haemorrhage or hemorrhage". A further search of commonly used treatments utilising the terms "hyperbaric oxygen*", "formalin", "aluminium", "ablation or laser" and "oral therapy" was performed. Results were limited to publications in the English language, involving adult human patients and published after 1990. Reference lists were checked to identify relevant studies not captured in the initial search. Reviews and case reports were excluded and, where possible, studies including patients who had received either radiation or cyclophosphamide, as a precursor, were filtered to assess intervention effect on those who received radiation therapy only. Abstracts and complete manuscripts were reviewed individually by two authors and discrepancies reviewed by a third party.

This article is protected by copyright. All rights reserved 
Inclusion criteria were studies describing onset of haematuria $\geq 3$ months post completion of radiation therapy and pelvic radiation for any cause. For comparative purposes, outcomes were classified as either complete response (CR) corresponding to resolution of haematuria, partial response (PR) corresponding to improvement but not resolution of haematuria or treatment failure (TF) corresponding to requirement of alternative intervention for persistent severe haematuria. Those denoted as "unknown" were patients that were lost to follow up or patients that discontinued a trial.

224 manuscripts were identified through database search and a further five were included after identification through other sources. After removal of duplicates and further screening by title and abstract to ensure adherence with inclusion and exclusion criteria 51 articles were further assessed for eligibility. Due to the heterogeneity of the clinical causes for haemorrhagic cystitis, articles were excluded due to absence of previous pelvic radiation as a underlying cause of the haemorrhagic cystitis. A total of 28 studies were included for qualitative synthesis. Within these studies, patient groups were small and not divided by underlying malignancy and as such all eligible studies including patients with haemorrhagic radiation cystitis were reviewed.

\subsection{Treatment options}

A variety of treatment options are described for radiation induced hemorrhagic cystitis. These management strategies can be subclassified into systemic medical therapies, hyperbaric oxygen, intravesical, ablative, interventional radiological and definitive surgical techniques. Their advantages, disadvantages and most recent comparative data on clinical efficacy are discussed in detail below.

\subsection{Systemic therapies}

Medical systemic therapies for haemorrhagic cystitis are appealing as they are noninvasive and circumvent inpatient hospital admission (Table 1). WF10 is an intravenous formulation, manufactured from the drug substance OXO K993, also referred to as Tetrachlorodecaoxygen (TCDO). Its proposed mechanism of action for treating haemorrhagic radiation cystitis relies on the model of a post irradiated bladder being in a state of chronic inflammation. WF10 induces natural immunity 
and stimulates cellular defence mechanisms through its actions on natural killer cells (NKTCs), cytotoxic T-lymphocytes, and modification of the monocyte-macrophage system. It reduces inflammation promptly so that a host-derived healing can commence [9]. In one randomised controlled trial, Veerasan et al. demonstrated that patients treated with WF10 $(n=37)$ had a significantly decreased rate of recurrent haematuria recurrence after 12 months (47\% vs $77 \%, p=0.01)$ [9]. A potential limitation to this study is that the treatment failure group in both arms may be over-estimated as details of partial response were not described. Table 1 summarises patients' response rate with WF10 in detail.

Sodium pentosan polysulphate (SPP) is a synthetic sulphated polysaccharide that is used to decrease urothelial permeability by replacing defective GAGs. Sandhu et al. assessed SPP, oral administration of 100mg three times daily, for managing radiation induced haemorrhagic cystitis in 60 patients. In total, 51 patients were available for follow-up and the dose was gradually reduced to a maintenance dose of $100 \mathrm{mg}$ in 21 patients due to PR. In 10 patients SPP was stopped due to CR. A limitation with medical therapies, as noted by the authors, is 'time to effect' [10]. The onset of action was 1-8 weeks. In this timeframe, 15 patients required inpatient admission for bladder irrigation; of which 5 required irrigation under general anaesthetic and 14 required blood transfusions [10].

Tranexamic acid has been used to treat urological haemorrhagic emergencies however evidence of efficacy in the haemorrhagic radiation cystitis patient is lacking. It can be administered in the initial resuscitation and conservative management phases of active haemorrhage in patients with prior radiotherapy. As tranexamic acid acts by inhibiting fibrinolysis, attention must be directed at preventing formation of large thrombi with resultant clot urinary retention. Tranexamic acid has been associated with increased risk of thromboembolic events however the evidence not clear. It may be considered in problematic acute surgical bleeding such as in haemorrhagic radiation cystitis however complications of clot retention limit its use. [11] 


\subsection{Hyperbaric oxygenation}

The underlying pathophysiology of radiation cystitis involves a progressive end arteritis that leads to poor tissue oxygenation and eventual tissue ischemia. Necrosis and tissue sloughing ensues with fibroblast deposition on ischaemic tissue layers. Compensatory neovascularisation and telangiectasia leads a friable vascular network with resultant haematuria. Hyperbaric oxygen (HBO) therapy increases oxygen delivery to tissues by increasing the amount of dissolved oxygen in the plasma to induce and restore normal reparation of granulocytes and fibroblasts. Administration of $\mathrm{HBO}$ has been shown to induce neo-angiogenesis with restoration of $\leq 80 \%$ of capillary density [12-14]. Studies reporting on outcomes of HBO are mainly retrospective in patients who have failed conservative management for radiation-induced haemorrhagic cystitis. Their main findings are summarised in table 2 with complete resolution of haematuria occurring in $34-87.5 \%$ of patients. Commencement of HBO within 6 months of haematuria increases the potential of complete resolution to $96 \%$ [15]. With HBO, patients spend 90 minutes 5-7 days per week in a hyperbaric chamber inspiring $100 \%$ oxygen between 2-2.4 atmospheres (ATMs). A total of $40 \mathrm{HBO}$ treatments extending over an 8-week period are typically administered [16]. The follow up of patients following HBO varied between 12-120 months, with the majority of patients being followed up for a mean of 24 months of less, as outlined in table 2. As such, the evidence for long-term efficacy of HBO in the treatment of haemorrhagic radiation cystitis is lacking.

\subsection{Intravesical therapies}

Contemporary evidence and outcomes for intravesical therapies are summarised in Table 3. Response rates with these agents typically range from $60-90 \%$. Historical evidence-based intravesical therapies for the treatment of haemorrhagic radiation cystitis are instillations of formalin and alum [17]. Formalin functions by precipitating cellular proteins within the epithelial layer causing occlusion fixation of the telangiectatic and friable microvasculature. There is limited contemporary evidence on the use of formalin and devastating complications, such as patient mortality, have 
been described with concentrations of $2-4 \%$. Notably, lower concentrations demonstrate equivalent clinical efficacy with a lower complication rate [18, 19]. A contemporary study of 8 patients with haemorrhagic radiation cystitis, treated with formalin instillation, 7 of whom had failed other therapies, describes a response in 6, patients. However, 5 of the 8 patients required blood transfusions within 30 days of instillation, one patient developed acute kidney injury and respiratory failure requiring intensive care management. Urinary diversion was required in 2 patients that did not respond and in 1 patient that developed recurrent symptoms [20]. Therefore, formalin is only recommended in cases of intractable haemorrhagic cystitis that may require urinary diversion [21]. Aluminium salts (usually potassium or ammonium aluminium sulphate) act by precipitating proteins on the surface of cells. Intravesical instillation of alum is not as effective as formalin but is associated with an improved side-effect profile and may represent an early treatment option if initial more conservative measures are unsuccessful. [17]

More recently, novel intravesical therapies have aimed to replenish the glycosaminoglycan (GAG) protective layer to reduce exposure of underlying epithelial cells to host urine. Hyaluronic acid is a major mucopolysaccharide than can be instilled into the urinary bladder. It has immunomodulatory properties that enhance connective tissue healing [22]. Epsilon aminocaproic acid inhibits fibrinolysis to counteract urokinase on exposed telangiectatic vessels in the postradiation bladder and can be instilled into the bladder. Singh et al. described intravesical instillation in 37 patients with intractable haemorrhage associated with radiation or chemotherapy induced cystitis and reported a partial or complete response rate in 34 patients (92\%) [23]. Other intravesical therapies have been described in smaller case series'. Silver nitrate (0.01-0.4\%) was ineffective for managing haemorrhage in 9 patients with radiation cystitis [24]. Several other agents, including prostaglandins, botulinum toxin, polydeoxyribonucleotides and early placental extract, have also been reported with limited response rates [22].

\subsection{Ablative therapies}


Ablation and coagulation of ruptured submucosal vasculature with laser (yttriumaluminium-garnet [YAG] and Greenlight(C) therapy or argon beam therapies is advantageous as both modalities can immediately control haemorrhage and are associated with complete response in $75-97.5 \%$ of cases (Table 4). Disadvantages with these modalities are requirement of general or spinal anaesthesia. Greenlight $@$ laser can ablate blood vessels with selective absorption of green light by intravascular oxy-haemoglobin thereby sparing the surrounding tissue [25]. Conversely, the YAG laser is non-selective and has an increased risk of bladder or bowel perforation in conjunction with irritative post procedural urological symptoms due to sloughing of necrotic tissue [26]. Argon beam coagulation does not use laser technology. Instead, the bladder is filled with argon gas and an argon probe is directed approximately $3 \mathrm{~mm}$ from the vessel and a monopolar current is aimed towards it. Uniquely, argon ablative therapy has a safety mechanism for preventing perforation as the current follows the path of least resistance and moves onto adjacent tissue after coagulation has been achieved. Also, the depth of ablation can be altered by adjusting power and gas flow settings [5].

\subsection{Interventional radiological}

There is limited evidence on arterial embolisation for managing haemorrhagic radiation cystitis. Small case series describe clinical scenarios of haemorrhagic radiation cystitis combined with additional causes of intractable haematuria originating from the urinary bladder or prostate gland. In these series, resolution of haematuria varies from $90-100 \%$ and is dependent on the underlying patient group requiring embolisation $[27,28]$. Long-term resolution of haematuria ranges from $70-$ $81 \%$ after a median follow-up of 16-18 months. Loffroy et al [29] found that embolisation can be selected to treat any cause of intractable haematuria (including radiation cystitis) as complete resolution occurs in $92.6-100 \%$ of patients. Notably, depending on the selectivity of embolization, ischaemic complications occur in 10$62.5 \%$ and may include skin or bladder necrosis, gluteal paresis, Brown-Sequard syndrome, and perineal or buttock pain.

\subsection{Definitive surgical treatment}

This article is protected by copyright. All rights reserved 
Urinary diversion with or without cystectomy can be performed if all other less invasive treatment modalities have failed. One series on 21 patients undergoing cystectomy and urinary diversion for intractable haemorrhagic cystitis demonstrated that $42 \%$ of patients developed a complication that was either Clavien-Dindo Grade III or Grade IV during the perioperative period. Furthermore, the 90 day mortality was $16 \%$ and overall survival at one year was $84 \%$ [8].

\subsection{Management algorithm}

There are no widely adopted definitive treatment algorithms for managing patients with radiation-induced haematuria. Therefore, definitive and effective treatment of this patient population is often challenging for the urologist. To optimise clinical outcomes in this difficult patient cohort; we propose the following stepwise, evidence-based approach to treatment of the acutely haemorrhagic patient (Fig. 1). A clinical guide to each step in the algorithm can be found in Table 5 .

\subsection{Haemorrhagic radiation cystitis with active bleeding}

Acute active bleeding in the setting of previous pelvic radiotherapy can result in hypovolaemic shock. Therefore, we advocate inpatient admission for patients with acute haemorrhagic radiation cystitis. Initial management involves stabilisation with fluid resuscitation, insertion of a large $24-26 \mathrm{Fr} 3$-way indwelling catheter (IDC), manual washout with extensive clot evacuation and commencement of continuous bladder irrigation (CBI). Tranexamic acid, administered orally, intravenously or intravesically, may be considered in the initial conservative management of urological haemorrhage.[30]

A thorough patient history and physical examination should be performed to exclude other causes of haematuria such as urinary tract infection, anti-thrombotic agents, pre-existing urological malignancy, benign prostatic hyperplasia (BPH), urinary stone disease and known underlying coagulopathies. Laboratory investigations including full blood count, blood urea, serum creatinine and coagulation profile should be performed. Urinalysis and urine culture should be performed to rule out infection. 
Urine cytology can be performed if the patient is at risk of bladder cancer however this may be difficult to interpret. Computed Tomography (CT) with intravenous pyelography may be performed to rule out upper tract bleeding.

Rigid cystoscopy should initially be performed in all patients to further rule out bladder malignancy and confirm the diagnosis of radiation cystitis. At this stage further clot evacuation and fulguration with diathermy can be performed at this time if required. If conservative measures fail, ablative therapies should be performed which may lead to immediate control of the bladder haemorrhage. This process can be repeated if required. If ablative resources are not available, then intravesical aluminium may be administered.

When minimally invasive measures are unsuccessful we recommend consideration of bladder preserving urinary diversion with bilateral nephrostomies or an ileal conduit. Embolisation can also be considered at this time. If bleeding persists despite urinary diversion, intravesical formalin at a non-toxic concentration may be considered however definitive cystectomy may at this stage be required. Finally, we suggest consolidation with hyperbaric oxygen in patients undergoing bladder preservation treatment strategies once bleeding has been controlled and the patient is stable.

\subsection{Haemorrhagic radiation cystitis with bothersome intermittent bleeding.} Bothersome intermittent bleeding can be defined as multiple episodes of frank haematuria for which patients seek medical attention or microscopic haematuria resulting in a haemoglobin drop that requires medical attention. As detailed above, these patients should undergo thorough clinical investigation to rule out other cause for bladder haemorrhage. Part of this diagnostic work up should initially include a rigid cystoscopy to further rule out other cause for bleeding including bladder malignancy and enable diagnosis of radiation cystitis. Bladder wash out and fulguration or ablation of bleeding or immanently bleeding vessels can be performed at this time. 
Hyperbaric oxygen for management of haemorrhagic radiation cystitis has the most robust evidence for efficacy, however it is cumbersome for patients requiring long duration of treatment and a certain level of fitness that many patients with radiation cystitis will not achieve. Patients with intermittent self-limiting episodes of bleeding should be prescribed hyperbaric oxygenation, where possible, and considered for medical systemic or intravesical therapies. There are no direct comparative trials between oral and intravesical therapy for the management of haemorrhagic radiation cystitis. As such, we advocate a step-by-step management algorithm that can be tailored to the specific clinical situation of each patient with consideration of the side effect profile and acceptability of the intervention. These patients should also be offered regular follow-up appointments in the urology outpatients department.

\section{Future perspectives and conclusions}

The relationship between novel pelvic radiation techniques and haemorrhagic radiation cystitis will become apparent in future, as symptoms can develop $\geq 10$ years once radiotherapy has been completed. In the interim, many treatment options are available for the management of chronic radiation cystitis, however level one evidence is lacking. Medical systemic therapies are appealing as they are non-invasive but are most efficient for chronic haemorrhagic radiation cystitis. Hyperbaric oxygen therapy is also non-invasive but requires commitment from patients and is not freely available as a healthcare resource. Intravesical therapy is associated with an acceptable short-term response rate, however limited evidence is available on durability. If laser ablative therapies are required, selection of the green light spectrum is preferable due to its more favourable safety-profile compared to YAG-laser. Most importantly, we advocate a stepwise management algorithm with multimodal treatment in patients presenting with severe acute haemorrhagic radiation cystitis.

\subsection{References}

[1] Smit SG, Heyns CF. Management of radiation cystitis. Nature Reviews Urology. 2010 Apr: 7:206-14 
[2] Zelefsky M. J CH, Hunt M, Yamanda Y, Shippy A and Amold H. Long-term outcome of high dose intensity modulated radiation therapy for patients with clinically localised prostate cancer. . J Urol. 2006: 176:1415-9

[3] Marks LBC, P R; Dugan, T C; Anscher, M S. The response of the urinary bladder, urethra, and ureter to radiation and chemotherapy. [Review] International journal of radiation oncology, biology, physics. 1995: 31:1257-80

[4] Ma JL, Hennessey DB, Newell BP, Bolton DM, Lawrentschuk N. Radiotherapy-related complications presenting to a urology department: a more common problem than previously thought? BJU International. 2018:

[5] Wines MP, Lynch WD. A new minimally invasive technique for treating radiation cystitis: the argon-beam coagulator. BJU International. 2006 Sep: 98:610-2

[6] Al Hussein Al Awamlh B, Lee DJ, Nguyen DP, Green DA, Shariat SF, Scherr DS. Assessment of the quality-of-life and functional outcomes in patients undergoing cystectomy and urinary diversion for the management of radiation-induced refractory benign disease. Urology. 2015 Feb: 85:394-400

[7] Cheng C aFK. Management of severe chronic radiation cystitis Ann Acad Med Singapore. 1992: 21:368-71

[8] Linder BJ, Tarrell RF, Boorjian SA. Cystectomy for refractory hemorrhagic cystitis: contemporary etiology, presentation and outcomes. J Urol. 2014 Dec: 192:1687-92

[9] Veerasarn V, Khorprasert C, Lorvidhaya V, et al. Reduced recurrence of late hemorrhagic radiation cystitis by WF10 therapy in cervical cancer patients: a multicenter, randomized, two-arm, open-label trial. Radiotherapy \& Oncology. 2004 Nov: 73:179-85

[10] Sandhu SS, Goldstraw M, Woodhouse CR. The management of haemorrhagic cystitis with sodium pentosan polysulphate. BJU Int. 2004 Oct: 94:845-7

[11] Reed R, Woolley, T. Uses of tranexamic acid. Continuing Education in Anaesthesia Critical Care \& Pain. 2015: 15:32-7

[12] Anderson LH WB, Herring RF, Mehm WJ. Influence of intermittent hyperoxia on hypoxic fibroblasts. J Hyperbaric Med. 1992: 7:103-14

[13] Weiss JP MD, Neville EC, Hanno PM. . Primary treatment of radiation- induced hemorrhagic cystitis with hyperbaric oxygen: 10-year experience. . J Urol 1994: 151:1514-7

This article is protected by copyright. All rights reserved 
[14] Muhonen A HM, Gronroos T, Bergman J, Knuuti J, Hinkka S, et al. Osteoblastic activity and neoangiogenesis in distracted bone of irradiated rabbit mandible with or without hyperbaric oxygen treatment. Int J Oral Maxillofac Surg 2004: 33:173-8

[15] Chong KT, Hampson NB, Corman JM. Early hyperbaric oxygen therapy improves outcome for radiation-induced hemorrhagic cystitis. Urology. 2005 Apr: 65:649-53

[16] Ribeiro de Oliveira TM, Carmelo Romao AJ, Gamito Guerreiro FM, Matos Lopes TM. Hyperbaric oxygen therapy for refractory radiation-induced hemorrhagic cystitis. Int J Urol. 2015 Oct: 22:962-6

[17] Smit SG, Heyns CF. Management of radiation cystitis. Nature reviews Urology. 2010 Apr: 7:206-14

[18] Dewan AK, Mohan GM, Ravi R. Intravesical formalin for hemorrhagic cystitis following irradiation of cancer of the cervix. International Journal of Gynaecology \& Obstetrics. 1993 Aug: 42:131-5

[19] Lojanapiwat B, Sripralakrit S, Soonthornphan S, Wudhikarn S. Intravesicle formalin instillation with a modified technique for controlling haemorrhage secondary to radiation cystitis. Asian J. 2002 Jul: 25:232-5

[20] Ziegelmann MJ, Boorjian, S., Joyce, D., Montgomery, B., Linder, B. Intravesical formalin for haemorrhagic cystitis: a contemporary cohort. The Canadian journal of urology. 2017: 11:E79-82

[21] Denton AS, Clarke NW, Maher EJ. Non-surgical interventions for late radiation cystitis in patients who have received radical radiotherapy to the pelvis. The Cochrane database of systematic reviews. 2002:Cd001773

[22] Browne CD, N.F.; Mac Craith, E., Lennon, G.M., Mulvin, D.W., Quinlan, D.M., McVey, G.P., Galvin, D.J. A Narrative Review on the Pathophysiology and Management for Radiation Cystitis. Advances in Urology. 2015: 2015

[23] Singh I, Laungani GB. Intravesical epsilon aminocaproic acid in management of intractable bladder hemorrhage. Urology. 1992 Sep: 40:227-9

[24] Montgomery BD, Boorjian SA, Ziegelmann MJ, Joyce DD, Linder BJ. Intravesical silver nitrate for refractory hemorrhagic cystitis. Turkish journal of urology. 2016 Sep: 42:197-201 [25] Talab SS, McDougal WS, Wu CL, Tabatabaei S. Mucosa-sparing, KTP laser coagulation of submucosal telangiectatic vessels in patients with radiation-induced cystitis: a novel approach. Urology. 2014 Aug: 84:478-83

This article is protected by copyright. All rights reserved 

resection for treating benign prostatic obstruction: a systematic review. The Journal of Urology. 2003 Jan 2003: 169:210-15

[27] Delgal AC, J.P.;Koutlidis, N.; Michel, F.;, Kermarrec IM, E.; Cormier, L.; Krausé,D.; Loffroy, R. Outcome of Transcatheter Arterial Embolization for Bladder and Prostate Hemorrhage. THE JOURNAL OF UROLOGY. 2010: 183:1947-53

[28] Korkmaz MS, B.; Aras, B.; Bozkaya, H., Cinar, C., Guneyli, S., Gok, M., Adam, G., Duzgun, F., Oran, I. The short- and long-term effectiveness of transcatheter arterial embolization in patients with intractable hematuria. Diagnostic and Interventional Imaging. 2016: 97:197-201

[29] Loffroy R, Pottecher P, Cherblanc V, et al. Current role of transcatheter arterial embolization for bladder and prostate hemorrhage. Diagn Interv Imaging. 2014 Nov:

95:1027-34

[30] Thompson A, Adamson, A., Bahl, A., Borwell, J., Dodds, D., Heath, C., Huddart, R., McMenemin, R., Patel, P., Peters, J., Payne, H. Guidelines for the diagnosis, prevention and management of chemical- and radiation-induced cystitis. Journal of Clinical Urology. 2013: 7:25-35

[31] Yoshida T, Kawashima A, Ujike T, Uemura M, Nishimura K, Miyoshi S. Hyperbaric oxygen therapy for radiation-induced hemorrhagic cystitis. Int J Urol. 2008 Jul: 15:639-41

[32] Degener S, Pohle A, Strelow H, et al. Long-term experience of hyperbaric oxygen therapy for refractory radio- or chemotherapy-induced haemorrhagic cystitis. BMC urology. 2015: 15:38

[33] Corman JM, McClure D, Pritchett R, Kozlowski P, Hampson NB. Treatment of radiation induced hemorrhagic cystitis with hyperbaric oxygen. J Urol. 2003 Jun: 169:2200-2 [34] Neheman A, Nativ O, Moskovitz B, Melamed Y, Stein A. Hyperbaric oxygen therapy for radiation-induced haemorrhagic cystitis. BJU International. 2005 Jul: 96:107-9 [35] Polom W, Klejnotowska A, Matuszewski M, Sicko Z, Markuszewski M, Krajka K. Hyperbaric oxygen therapy (HBOT) in case of hemorrhagic cystitis after radiotherapy. Cent. 2012: 65:200-3

[36] Schwalenberg T, Berger FP, Horn LC, Thi PH, Stolzenburg JU, Neuhaus J. Intravesical Glycosaminoglycan Replacement with Chondroitin Sulphate (Gepan() instill) in Patients with 
Chronic Radiotherapy- or Chemotherapy-Associated Cystitis. Clin Drug Invest. 2015 Aug: 35:505-12

[37] Shao Y, Lu GL, Shen ZJ. Comparison of intravesical hyaluronic acid instillation and hyperbaric oxygen in the treatment of radiation-induced hemorrhagic cystitis. BJU International. 2012 Mar: 109:691-4

[38] Vasssilis K EM, Andreas F, Ivelina B, Charalampos A, et al. Use of Hyaluronic Acid (Cystistat) for the Treatment of Late Radiation Induced Cystitis in Patients after Prostate Irradiation. Journal of Bioequivalence \& Bioavailability. 2014: 6:018-22

[39] Westerman MEB, S.A.; Linder, B.J. Safety and Efficacy of Intravesical alum for intractable haemorrhagic cystitis: A contemporary evaluation. Int Braz J Urol. 2016: 42:1144-9

[40] Goswami AKM, R.K.; Nath, R.; Sharma, S.K. How safe is $1 \%$ Alum irrigation in controlling intractable vesical hemorrhage? J Urol. 1993: 149:264-7

[41] Vicente JR, G.; Caffaratti, J.;. Intravesical formalin for the treatment of massive haemorrhagic cystitis: retrospective review of 25 cases. European urology. 1990: 18:204-6

[42] Ravi R. Endoscopic neodymium:YAG laser treatment of radiation-induced hemorrhagic cystitis. Lasers in Surgery \& Medicine. 1994: 14:83-7

[43] Martinez DR, Ercole CE, Lopez JG, Parker J, Hall MK. A Novel Approach for the Treatment of Radiation-Induced Hemorrhagic Cystitis with the GreenLightTM XPS Laser. Int Braz J Urol. 2015 May-Jun: 41:584-7

[44] B. Lamb CP, D. Christidis, DG. Murphy, N. Lawrentschuk and TE. Manning. Green Light Laser for management of hemorrhagic cystitis - a novel technique and initial results. BJU Int. 2018: 121:58-91

[45] Veerasarn V, Boonnuch W, Kakanaporn C. A phase II study to evaluate WF10 in patients with late hemorrhagic radiation cystitis and proctitis. Gynecol Oncol. 2006 Jan: 100:179-84

[46] Sandhu SS, Goldstraw M, Woodhouse CR. The management of haemorrhagic cystitis with sodium pentosan polysulphate. BJU Int. 2004 Oct: 94:845-7

This article is protected by copyright. All rights reserved 


\begin{tabular}{|c|c|c|c|c|c|c|c|c|}
\hline GROUP & DRUG & STUDY TYPE & $\mathbf{N}$ & $\begin{array}{l}\text { MEAN } \\
\text { RADIATION } \\
\text { DOSE } \\
\end{array}$ & $\begin{array}{c}\text { MEAN NUMBER AND } \\
\text { (DURATION OF TREATMENT) }\end{array}$ & FOLLOW-UP & $\begin{array}{l}\text { ADVERSE } \\
\text { EVENTS }\end{array}$ & OUTCOME \\
\hline \multirow[t]{2}{*}{$\begin{array}{l}\text { VEERASAN, } \\
2004 \text { [9] }\end{array}$} & \multirow[t]{2}{*}{$\begin{array}{l}\text { WF10 } \\
\text { (Immunokine) }\end{array}$} & \multirow[t]{2}{*}{$\begin{array}{l}\text { Randomised, } \\
\text { open arm, two- } \\
\text { label }\end{array}$} & \multirow[t]{2}{*}{$\begin{array}{l}102 \text { (51 in } \\
\text { treatment } \\
\text { arm) }\end{array}$} & \multirow[t]{2}{*}{ Not described } & \multirow[t]{2}{*}{10 (6 weeks) } & \multirow[t]{2}{*}{ 7-52 weeks } & \multirow[t]{2}{*}{ Headache, fever } & $\begin{array}{l}\text { Treatment } \\
{ }^{*} \mathrm{CR}=20 \\
\wedge \mathrm{TF}=29 \\
\text { Unknown=2 }\end{array}$ \\
\hline & & & & & & & & $\begin{array}{l}\text { Control } \\
{ }^{*} \mathrm{CR}=8 \\
\wedge \mathrm{TF}=40 \\
\text { Unknown=2 }\end{array}$ \\
\hline $\begin{array}{l}\text { SANDHU, } 2004 \\
{[10]}\end{array}$ & \begin{tabular}{|l} 
Sodium \\
Pentosan \\
Polusulfate
\end{tabular} & Prospective & 60 & Not described & 180 (21-1745 days) & $\begin{array}{l}450(19-4526) \\
\text { days }\end{array}$ & nil & $\begin{array}{l}{ }^{*} \mathrm{CR}=10 \\
* * \mathrm{PR}=21 \\
\mathrm{TF}=20 \\
\text { Unknown=9 }\end{array}$ \\
\hline
\end{tabular}

Table 1: Summary of evidence for systemic medical therapies for the treatment of haemorrhagic radiation cystitis.

* complete resolution

** partial resolution

$\wedge$ treatment failure

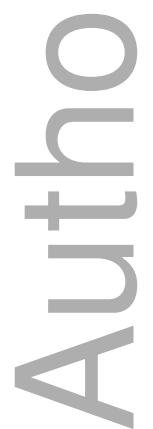

This article is protected by copyright. All rights reserved 
[9] Veerasarn V, Khorprasert C, Lorvidhaya V, et al. Reduced recurrence of late hemorrhagic radiation cystitis by WF10 therapy in cervical cancer patients: a multicenter, randomized, two-arm, open-label trial. Radiotherapy \& Oncology. 2004 Nov: 73:179-85

[10] Sandhu SS, Goldstraw M, Woodhouse CR. The management of haemorrhagic cystitis with sodium pentosan polysulphate. BJU Int. 2004 Oct: 94:845-7

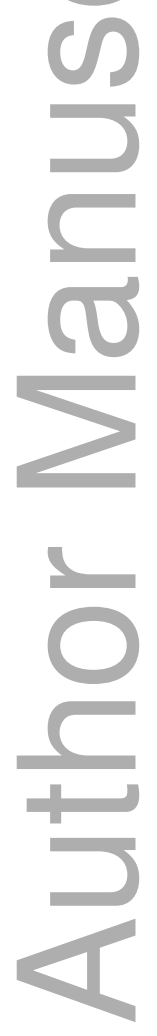

This article is protected by copyright. All rights reserved 


\begin{tabular}{|c|c|c|c|c|c|c|}
\hline GROUP & STUDY TYPE & $\mathbf{N}$ & $\begin{array}{c}\text { MEAN RADIATION } \\
\text { DOSE }\end{array}$ & $\begin{array}{c}\text { MEAN NUMBER OF } \\
\text { TREATMENTS }\end{array}$ & MEAN FOLLOW-UP & OUTCOME \\
\hline YOSHIDA, 2008 [31] & Retrospective & 8 & $56.6 \mathrm{~Gy}$ & 19 (10-42), 90min each & 15.5 months (2-34) & $\begin{array}{l}{ }^{*} \mathrm{CR}=7 .(87.5 \%) \\
\wedge \mathrm{TF}=2(2.5 \%)\end{array}$ \\
\hline CHONG, 2005 [15] & Retrospective & 60 & Not described & $33(9-63), 90 \mathrm{~min}$ each & 12 months & $\begin{array}{l}{ }^{*} \mathrm{CR}=21(35 \%) \\
* * \mathrm{PR}=27(45 \%) \\
\wedge \mathrm{TF}=10(17 \%) \\
\text { Unknown=2(3\%) }\end{array}$ \\
\hline DEGENER, 2015 [32] & Retrospective & 13 & 65 Gy (60-74) & $34(6-128), 90 \mathrm{~min}$ each & 68 months (16-142) & $\begin{array}{l}{ }^{*} \mathrm{CR}=11(84 \%) \\
* * \mathrm{PR}=1(8 \%) \\
\wedge \mathrm{TF}=1(8 \%)\end{array}$ \\
\hline CORMAN, 2003 [33] & Retrospective & 57 & Not described & $33(9-68), 90 \mathrm{~min}$ each & $\begin{array}{l}\text { Av not stated } \\
(10-120 \text { months })\end{array}$ & $\begin{array}{l}* \mathrm{CR}=21(34 \%) \\
* * \mathrm{PR}=28(45 \%) \\
\wedge \mathrm{TF}=8(13 \%) \\
\text { Unknown }=5(8 \%)\end{array}$ \\
\hline NEHMAN, 2005 [34] & Prospective & 7 & $64 \sim \mathrm{Gy}$ & $30(18-57)$ & 24 months (3-53) & ${ }^{*} \mathrm{CR}=7(100 \%)$ \\
\hline POLOM, 2012 [35] & Retrospective & 10 & $72.6 \sim \mathrm{Gy}$ & $43.4(8-60)$ & 24.5 months (7-48) & $\begin{array}{l}{ }^{*} \mathrm{CR}=6(60 \%) \\
{ }^{* *} \mathrm{PR}=3(30 \%) \\
{ }^{\wedge} \mathrm{TF}=1(10 \%)\end{array}$ \\
\hline OLIVEIRA, 2015 [16] & Retrospective & 176 & $56.27 \sim \mathrm{Gy}$ & $36.53(7-179)$ & 12 (months) (0-108) & $\begin{array}{l}{ }^{*} \mathrm{CR}=118(67 \%) \\
* * \mathrm{PR}=40(23 \%) \\
\wedge \mathrm{TF}=18(10 \%)\end{array}$ \\
\hline
\end{tabular}

Table 2: Summary of evidence for hyperbaric oxygen for the treatment of haemorrhagic radiation cystitis.

$\sim$ Gray

* complete resolution

** partial resolution

$\wedge$ treatment failure

This article is protected by copyright. All rights reserved 
[15] Chong KT, Hampson NB, Corman JM. Early hyperbaric oxygen therapy improves outcome for radiation-induced hemorrhagic cystitis. Urology. 2005 Apr: 65:649-53

[16] Ribeiro de Oliveira TM, Carmelo Romao AJ, Gamito Guerreiro FM, Matos Lopes TM. Hyperbaric oxygen therapy for refractory radiationinduced hemorrhagic cystitis. Int J Urol. 2015 Oct: 22:962-6

[31] Yoshida T, Kawashima A, Ujike T, Uemura M, Nishimura K, Miyoshi S. Hyperbaric oxygen therapy for radiation-induced hemorrhagic cystitis. Int J Urol. 2008 Jul: 15:639-41

[32] Degener S, Pohle A, Strelow H, et al. Long-term experience of hyperbaric oxygen therapy for refractory radio- or chemotherapy-induced haemorrhagic cystitis. BMC urology. 2015: 15:38

[33] Corman JM, McClure D, Pritchett R, Kozlowski P, Hampson NB. Treatment of radiation induced hemorrhagic cystitis with hyperbaric oxygen. JUrol. 2003 Jun: 169:2200-2

[34] Neheman A, Nativ O, Moskovitz B, Melamed Y, Stein A. Hyperbaric oxygen therapy for radiation-induced haemorrhagic cystitis. BJU International. 2005 Jul: 96:107-9

[35] Polom W, Klejnotowska A, Matuszewski M, Sicko Z, Markuszewski M, Krajka K. Hyperbaric oxygen therapy (HBOT) in case of hemorrhagic cystitis after radiotherapy. Cent. 2012: 65:200-3

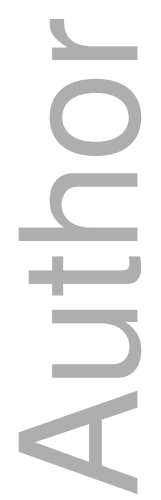

This article is protected by copyright. All rights reserved 


\begin{tabular}{|c|c|c|c|c|c|c|c|c|}
\hline GROUP & DRUG & STUDY TYPE & $\mathbf{N}$ & $\begin{array}{c}\text { MEAN } \\
\text { RADIATION } \\
\text { DOSE } \\
\end{array}$ & $\begin{array}{l}\text { MEAN NUMBER AND DURATION OF } \\
\text { TREATMENTS }\end{array}$ & $\begin{array}{l}\text { MEAN } \\
\text { FOLLOW- } \\
\text { UP } \\
\end{array}$ & ADVERSE EVENTS & OUTCOME \\
\hline $\begin{array}{l}\text { SCHWALENBER, } 2015 \\
\text { [36] }\end{array}$ & IV chonrdoitin & Observational & 16 & $\overline{l \wedge \wedge N R}$ & $\begin{array}{l}6 \times \text { weekly instillation } 0.2 \% \\
\text { chondroitin } 40 \mathrm{ml}\end{array}$ & 6 weeks & $\mathrm{Nil}$ & $\begin{array}{l}100 \%{ }^{*} \mathrm{CR} \text { of haematuria, } 81 \\
{ }^{*} \mathrm{CR} /{ }^{* *} \mathrm{PR} \text { other symptoms }\end{array}$ \\
\hline \multirow[t]{2}{*}{ SHAO, $2012[37]$} & \multirow{2}{*}{$\begin{array}{l}\text { IV hyaluronic } \\
\text { acid vs HBOT }\end{array}$} & \multirow[t]{2}{*}{ RCT } & \multirow[t]{2}{*}{36} & \multirow[t]{2}{*}{$45-70 \sim \mathrm{Gy}$} & $\begin{array}{l}\text { Intervention (hyaluronic acid): } 40 \mathrm{mg} \\
\text { weekly } \times 4 \text {, monthly } \times 2\end{array}$ & \multirow[t]{2}{*}{$\begin{array}{l}18 \\
\text { months }\end{array}$} & \multirow[t]{2}{*}{ nil } & $\begin{array}{l}\text { HA Group } \\
{ }^{*} \text { CR: } 50 \% ; * * \text { PR: } 75 \%\end{array}$ \\
\hline & & & & & $\begin{array}{l}\text { Control (HBOT): } 30 \times \text { daily } 60 \mathrm{~min} \\
2.5 \mathrm{~atm} \text { absolute }\end{array}$ & & & $\begin{array}{l}\text { Control Group (HBOT) : } \\
{ }^{*} \text { CR } 45 \% ; * * \text { PR } 75 \%\end{array}$ \\
\hline VASSSILIS, 2014 [38] & $\begin{array}{l}\text { IV hyaluronic } \\
\text { acid }\end{array}$ & $\begin{array}{l}\text { Prospective } \\
\text { observational }\end{array}$ & 20 & 72-74 Gy & $4 x$ weekly then 2 monthly & 6 months & nil & $\begin{array}{l}\text { Downgrading of radiation } \\
\text { cystitis from Grade III/II 70/ } \\
\text { to II/I } 55 / 45 \% \\
\end{array}$ \\
\hline SINGH, 1992 [23] & \begin{tabular}{|l} 
Epsilon \\
aminocaproic \\
acid
\end{tabular} & Observational & 37 & $\wedge^{\wedge \wedge N R}$ & $\wedge \wedge N R$ & ^^NR & Nil & $\begin{array}{l}\text { Response (combined } \\
{ }^{*} \text { CR/**PR) } 34(92 \%)\end{array}$ \\
\hline WESTERMAN, 2016 [39] & Alum 1\% & $\begin{array}{l}\text { Retrospective } \\
\text { Observational }\end{array}$ & 40 & ${ }^{\wedge \wedge N R}$ & $\begin{array}{l}1 \% \text { alum at } 250-300 \mathrm{cc} / \mathrm{hr} \text { for variable } \\
\text { duration }\end{array}$ & $\begin{array}{l}16.4 \\
\text { months }\end{array}$ & $\begin{array}{l}38 \% \text {, bladder spasms, transient delirium, } \\
\text { UTI }\end{array}$ & $\begin{array}{l}\text { CR } 60 \% \text {, - durable respons } \epsilon \\
54 \% \text { of responders }(1 / 3 \text { of } \\
\text { total) }\end{array}$ \\
\hline GOSWAMI, 1993 [40] & Alum $1 \%$ & Observational & $2 / 12$ & ${ }^{\wedge \wedge N R}$ & ^^NR & ^^NR & Transient low-grade pyrexia & ${ }^{*} \mathrm{CR} 4,{ }^{* *} \mathrm{PR} 6$ \\
\hline $\begin{array}{l}\text { ZIEGELMANN, } 2017 \\
{[20]}\end{array}$ & Formalin & $\begin{array}{l}\text { Retrospective } \\
\text { observational }\end{array}$ & 8 & ${ }^{\wedge \wedge} \mathrm{NR}$ & $\begin{array}{l}1 \% \text { formalin single instillation in } 5 / 8 . \\
2^{\text {nd }} \text { instillation of } 1-2 \% \text { in } 2 / 8 \\
\text { patients. 3rd instillation of } 4 \% \text { in } 1 / 8\end{array}$ & 8 months & $\begin{array}{l}\text { Acute kidney injury, respiratory distress, } \\
\text { contracted bladder with urgency, } \\
\text { incontinence, bladder neck contracture } \\
\text { (in patient who received } 3 \text { instillations) }\end{array}$ & $\begin{array}{l}{ }^{*} \text { CR } 37 . \% \%, * * \text { PR } 37.5 \%,{ }^{\wedge} \\
\text { in25\% }\end{array}$ \\
\hline VICENTE, 1990 [41] & Formalin & Observational & 196 & ${ }^{\wedge \wedge N R}$ & Formalin $4 \%$ and $10 \%$ & $\wedge^{\wedge \wedge N R}$ & $\begin{array}{l}\text { Rectovaginal fistula, hydroutero- } \\
\text { nephrosis, extravasation }\end{array}$ & ${ }^{*} \mathrm{CR} /{ }^{* * P R}: 88 \%$ \\
\hline DEWAN, 1993 [18] & & Observational & 35 & $\begin{array}{l}\text { Average } 68 \\
\text { Gy }\end{array}$ & Formalin $1 \%, 2 \%$ and $4 \%$ & $\begin{array}{l}\text { ^^NR-up } \\
\text { to } 17 \\
\text { months }\end{array}$ & $\begin{array}{l}\text { Fever, frequency, dysuria, pain, } \\
\text { incontinence, hydronephrosis, VUR, } \\
\text { ureteral stenosis, vesicovaginal fistula, } \\
\text { death, decreased bladder capacity, death }\end{array}$ & $\begin{array}{l}{ }^{*} \mathrm{CR} 89 \%, * * \mathrm{PR} 8 \% \text { at } 8 \text { hou } \\
\text { with recurrence in } 7 \text { patien } 1 \\
\text { (median } 8 \text { months) }\end{array}$ \\
\hline \multirow[t]{2}{*}{$\begin{array}{l}\text { LOJANAPIWAT, } 2002 \\
\text { [19] }\end{array}$} & \multirow{2}{*}{ Formalin } & \multirow[t]{2}{*}{ Prospective } & \multirow[t]{2}{*}{19} & \multirow[t]{2}{*}{${ }^{\wedge \wedge N R}$} & $\begin{array}{l}\text { Group 1: } 4 \% \text { formalin instillation } 15 \\
\min \end{array}$ & \multirow[t]{2}{*}{$\begin{array}{l}25 \\
\text { months }\end{array}$} & $\begin{array}{l}\text { Group 1: Anuria, bilateral } \\
\text { hydronephrosis, vesicovaginal fistula, } \\
\text { septic death }\end{array}$ & Group 1:*CR 82\% \\
\hline & & & & & $\begin{array}{l}\text { Group 2: } 10 \% \text { formalin pledgets } \\
\text { at bleeding points } 15 \mathrm{~min}\end{array}$ & & Group 2: nil major & $\begin{array}{l}\text { Group } 2:{ }^{*} C R: 75 \%, 1 \text { pati } \\
\text { required } 2^{\text {nd }} \text { treatment }\end{array}$ \\
\hline
\end{tabular}

$\sim$ Gray

Table 3: Summary of evidence for intra-vesical therapies for the treatment of haemorrhagic radiation cystitis.

*complete resolution

** partial resolution

^treatment failure

This article is protected by copyright. All rights reserved 
[18] Dewan AK, Mohan GM, Ravi R. Intravesical formalin for hemorrhagic cystitis following irradiation of cancer of the cervix. International Journal of Gynaecology \& Obstetrics. 1993 Aug: 42:131-5

[19] Lojanapiwat B, Sripralakrit S, Soonthornphan S, Wudhikarn S. Intravesicle formalin instillation with a modified technique for controlling haemorrhage secondary to radiation cystitis. Asian J. 2002 Jul: 25:232-5

[20] Ziegelmann MJ, Boorjian, S., Joyce, D., Montgomery, B., Linder, B. Intravesical formalin for haemorrhagic cystitis: a contemporary cohort. The Canadian journal of urology. 2017: 11:E79-82

[23] Singh I, Laungani GB. Intravesical epsilon aminocaproic acid in management of intractable bladder hemorrhage. Urology. 1992 Sep:

40:227-9

[36] Schwalenberg T, Berger FP, Horn LC, Thi PH, Stolzenburg JU, Neuhaus J. Intravesical Glycosaminoglycan Replacement with Chondroitin Sulphate (Gepan() instill) in Patients with Chronic Radiotherapy- or Chemotherapy-Associated Cystitis. Clin Drug Invest. 2015 Aug: 35:505-12 [37] Shao Y, Lu GL, Shen ZJ. Comparison of intravesical hyaluronic acid instillation and hyperbaric oxygen in the treatment of radiation-induced hemorrhagic cystitis. BJU International. 2012 Mar: 109:691-4

[38] Vasssilis K EM, Andreas F, Ivelina B, Charalampos A, et al. Use of Hyaluronic Acid (Cystistat) for the Treatment of Late Radiation Induced Cystitis in Patients after Prostate Irradiation. Journal of Bioequivalence \& Bioavailability. 2014: 6:018-22

[39] Westerman MEB, S.A.; Linder, B.J. Safety and Efficacy of Intravesical alum for intractable haemorrhagic cystitis: A contemporary evaluation. Int Braz J Urol. 2016: 42:1144-9

[40] Goswami AKM, R.K.; Nath, R.; Sharma, S.K. How safe is 1\% Alum irrigation in controlling intractable vesical hemorrhage? J Urol. 1993:

149:264-7

[41] Vicente JR, G.; Caffaratti, J.;. Intravesical formalin for the treatment of massive haemorrhagic cystitis: retrospective review of 25 cases. European urology. 1990: 18:204-6

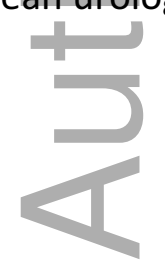

This article is protected by copyright. All rights reserved 


\begin{tabular}{|c|c|c|c|c|c|c|c|}
\hline STUDY & MODALITY & STUDY TYPE & $\mathbf{N}$ & $\begin{array}{c}\text { MEAN RADIATION } \\
\text { DOSE }\end{array}$ & $\begin{array}{c}\text { MEAN NUMBER OF } \\
\text { TREATMENTS }\end{array}$ & MEAN FOLLOW UP & OUTCOME \\
\hline WINES, 2006 [5] & $\begin{array}{l}\text { Argon beam } \\
\text { coagulator }\end{array}$ & Prospective & 7 & Not described & 1 & 15 months (6-36) & $\begin{array}{l}{ }^{*} \mathrm{CR}=6 .(86 \%) \\
\wedge \mathrm{TF}=1(4 \%)\end{array}$ \\
\hline RAVI, 1994 [42] & YAG Laser & Prospective & 42 & $68 \sim \mathrm{Gy}$ & 1 & 14 months & $\begin{array}{l}{ }^{*} \mathrm{CR}=41(97.5 \%) \\
\wedge \mathrm{TF}=1(2.5 \%)\end{array}$ \\
\hline TALAB, 2014 [25] & $\begin{array}{l}\text { KTP photo } \\
\text { selective } \\
\text { green light } \\
\text { laser }\end{array}$ & Retrospective & 20 & Not described & $1.3(1-3)$ & 14 months (1.7-37.1) & $\begin{array}{l}{ }^{*} \mathrm{CR}=15(75 \%) \\
\wedge \mathrm{TF}=3(15 \%) \\
\text { Unknown=2(10\%) }\end{array}$ \\
\hline $\begin{array}{l}\text { MARTINEZ, } 2015 \\
\text { [43] }\end{array}$ & $\begin{array}{l}\text { KTP photo } \\
\text { selective } \\
\text { green light } \\
\text { laser }\end{array}$ & Retrospective & 4 & Not described & 1 & 12 months & $\begin{array}{l}C^{*}=3(75 \%) \\
* * P R=1(25 \%)\end{array}$ \\
\hline
\end{tabular}

Table 4: Summary of evidence for ablative therapies for the treatment of haemorrhagic radiation cystitis.

Gray

* complete resolution

** partial resolution

$\wedge$ treatment failure

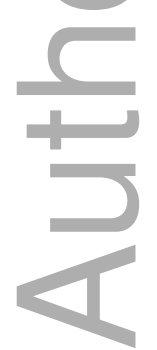

This article is protected by copyright. All rights reserved 
[5] Wines MP, Lynch WD. A new minimally invasive technique for treating radiation cystitis: the argon-beam coagulator. BJU International. 2006 Sep: $98: 610-2$

[25] Talab SS, McDougal WS, Wu CL, Tabatabaei S. Mucosa-sparing, KTP laser coagulation of submucosal telangiectatic vessels in patients with radiation-induced cystitis: a novel approach. Urology. 2014 Aug: 84:478-83

[42]Ravi R. Endoscopic neodymium:YAG laser treatment of radiation-induced hemorrhagic cystitis. Lasers in Surgery \& Medicine. 1994: 14:83-7

[43] Martinez DR, Ercole CE, Lopez JG, Parker J, Hall MK. A Novel Approach for the Treatment of Radiation-Induced Hemorrhagic Cystitis with the GreenLightTM XPS Laser. Int Braz J Urol. 2015 May-Jun: 41:584-7

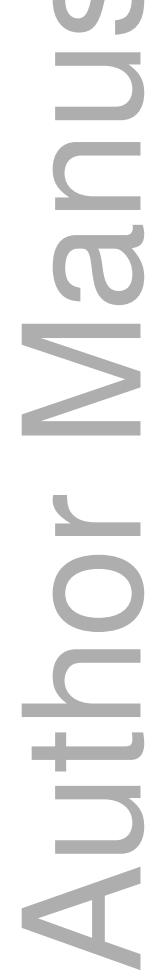

This article is protected by copyright. All rights reserved 


\begin{tabular}{|c|c|c|}
\hline Treatment & Equipment & Method \\
\hline $\begin{array}{l}\text { Acute bladder washout and } \\
\text { irrigation }\end{array}$ & $\begin{array}{l}\text { - Large (24-26Fr) 3-way IDC } \\
\text { - } 2 \text { L bags of Normal saline } \\
\text { (0.9\%) for continuous } \\
\text { irrigation } \\
\text { - Irrigation giving set } \\
\text { - Toomey syringe for clot } \\
\text { evacuation }\end{array}$ & $\begin{array}{l}\text { - Sterile technique with lubrication for standard catheter insertion with } \\
\text { large 3-way catheter. } \\
\text { - Using large Toomey or catheter syringe, manually evacuate blood } \\
\text { clots from bladder via large working channel of the catheter until no } \\
\text { further clots and output begins to clear. } \\
\text { - Establish irrigation through smaller channel using pump or standard IV } \\
\text { giving set raised at 1-2m from the ground (above the height of the } \\
\text { patient's bladder) } \\
\text { - Continue irrigation as needed. } \\
\text { - Repeat manual evacuation as required. }\end{array}$ \\
\hline Tranexamic Acid [11] & $\begin{array}{l}\text { - Need to evacuate clots from } \\
\text { bladder prior to } \\
\text { administration }\end{array}$ & $\begin{array}{l}\text { - Oral dose: } 1-1.5 \mathrm{~g}\left(15-25 \mathrm{mg} \mathrm{kg}^{-1}\right) 2-3 \text { times per day. } \\
\text { - I.V. dose: } 0.5-1 \mathrm{~g} \text { by slow injection three times per day, or following } \\
\text { initial dose, an infusion of } 25-50 \mathrm{mg} \mathrm{kg-10ver} 24 \mathrm{~h} \text {. } \\
\text { - In renal failure, reduce IV dose to } 5-10 \mathrm{mg} / \mathrm{kg}\end{array}$ \\
\hline Laser Ablation [44] & $\begin{array}{l}\text { - } 30 \text { degree } 24 \mathrm{Fr} \text { Rigid } \\
\text { cystoscope } \\
\text { - } 2 x 5 \mathrm{Fr} \text { ureteric catheters } \\
\text { - Energy source } \\
\text { - Laser fibre } \\
\text { - 22Fr 3-way indwelling } \\
\text { catheter } \\
\text { - urine bag } \\
\text { - large bore cannula } \\
\text { - Normal Saline for irrigation }\end{array}$ & $\begin{array}{l}\text { - Rigid cystoscopy } \\
\text { - Bilateral open ended } 5 \mathrm{Fr} \text { ureteric catheters } \\
\text { - laser set to } 80 \text { vaporisation, } 30 \text { coagulation (to be used around } \\
\text { ureteric orifices), } \\
\text { - active bleeding sites targeted first in order to optimise vision. } \\
\text { - Systematic lasering of the four quadrants of the bladder } \\
\text { - Ureteric catheters remain in situ for } 24 \mathrm{~h} \text {. } \\
\text { - Continue bladder irrigation (CBI) until urine clear } \\
\text { - Foley catheter \& ureteric catheters are removed within } 24 \text { hours to } \\
\text { minimise new inflammation secondary to foreign body } \\
\text { - Repeat process if required }\end{array}$ \\
\hline Aluminium [39] & $\begin{array}{l}\text { - Alum salts (usually potassium } \\
\text { alum) } 50 \mathrm{gm} \text { for } 5 \text { litres Sterile } \\
\text { water irrigation fluid }\end{array}$ & $\begin{array}{l}\text { - Dissolve } 50 \mathrm{gm} \text { of alum dissolved in } 5 \text { liters of sterile water } \\
\text { - Irrigate bladder at rate of } 250-300 \mathrm{cc} / \mathrm{hr} \\
\text { - Duration at discretion of the surgeon }\end{array}$ \\
\hline
\end{tabular}

This article is protected by copyright. All rights reserved 


\begin{tabular}{|c|c|c|}
\hline Formalin [20] & $\begin{array}{l}\text { - } 100-150 \mathrm{ml} \text { of Formalin } 1 \% \\
\text { - >18fr 3-way Foley catheter } \\
\text { - } 2 \text { x Fogarty catheter if } \\
\text { vesicoureteral reflux } \\
\text { - petroleum jelly }\end{array}$ & $\begin{array}{l}\text { - Intravesical administration under anaesthetic (spinal or general) } \\
\text { following cystoscopic removal of clots and any necrotic tissue, } \\
\text { fulguration of any actively bleeding areas and assessment of integrity } \\
\text { of bladder wall. Bladder emptied } \\
\text { - If vesicoureteral reflux, place Fogarty catheters to occlude ureteric } \\
\text { orifices. Protect external genitalia with petroleum jelly } \\
\text { - Instil } 1 \% \text { formalin through } 18 \mathrm{f} \text { catheter under gravity at }<15 \mathrm{~cm} \\
\text { pressure(3rd channel spigotted). Clamp catheter and apply traction to } \\
\text { avoid leakage around the balloon into the urethra. Instil for } 10-15 \\
\text { minutes. Empty bladder completely and resume copious normal saline } \\
\text { irrigation. }\end{array}$ \\
\hline WF10 [45] & $\begin{array}{l}\text { - WF } 10 \text { dose: } 0.5 \mathrm{ml} / \mathrm{kg} \text {, diluted } \\
\text { in } 250 \mathrm{ml} 5 \% \text { dextrose }\end{array}$ & $\begin{array}{l}\text { - IV administration over } 2 \text { hours } \\
\text { - Duration: daily for } 5 \text { consecutive days, every } 3 \text { weeks for 2-4 cycles }\end{array}$ \\
\hline $\begin{array}{l}\text { Sodium Pentosan Polysulphate } \\
\text { (SPP) [46] }\end{array}$ & - SPP $100 \mathrm{mg}$ tablets & $\begin{array}{l}\text { - Oral administration of SPP } 100 \mathrm{mg} \text { three times daily } \\
\text { - Treatment cessation with complete resolution of haematuria } \\
\text { - No monitoring required }\end{array}$ \\
\hline
\end{tabular}

Table 5: Clinical guide to administration of treatments for haemorrhagic radiation cystitis

This article is protected by copyright. All rights reserved 


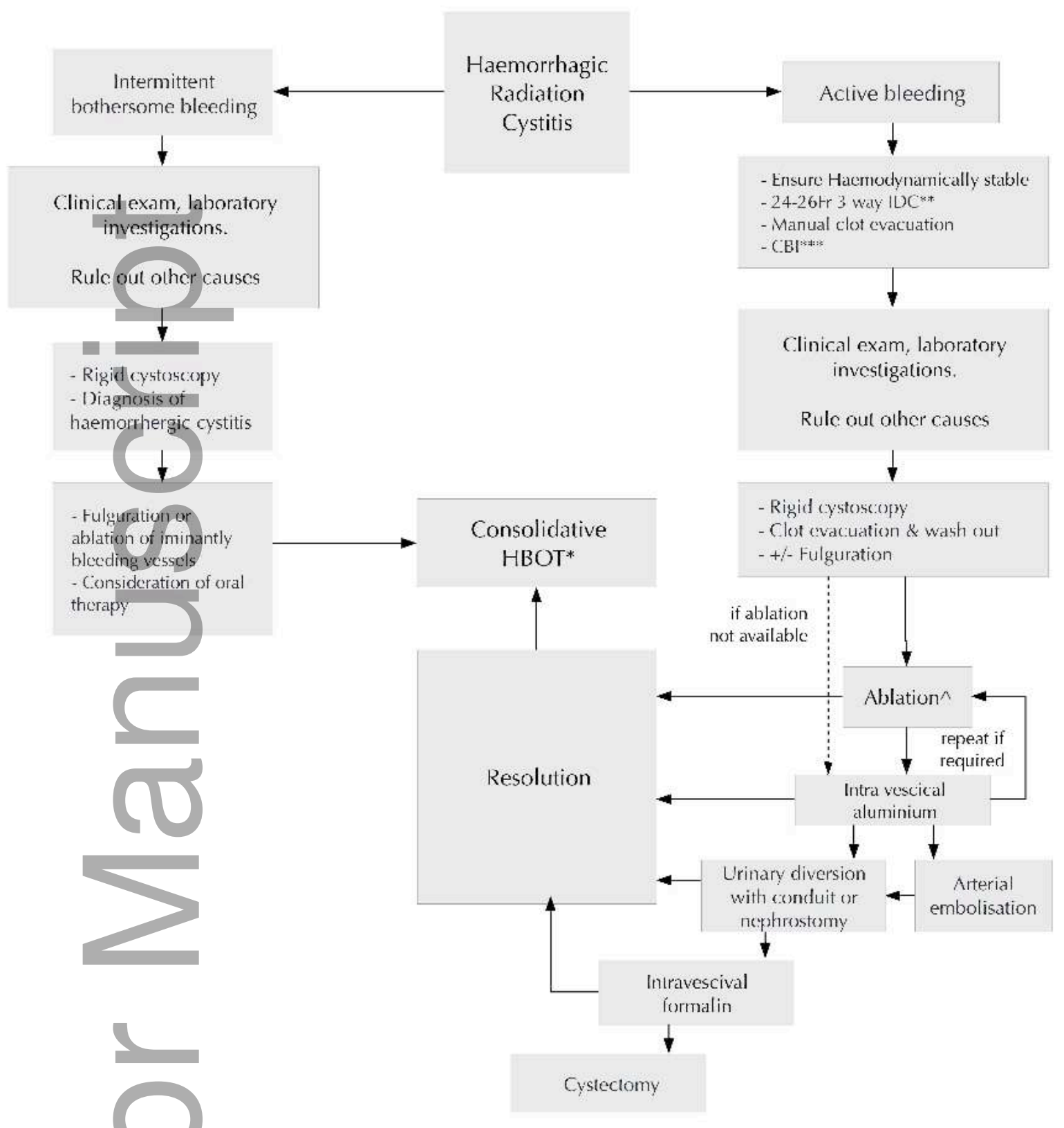

Figure 1: Practical management algorithm for radiation induced haemorrhagic cystitis

\section{*Hyerbaric Oxygen Therapy \\ ** Continuous Bladder Irrigation \\ $\wedge$ Bladder mucosal ablation therapy}




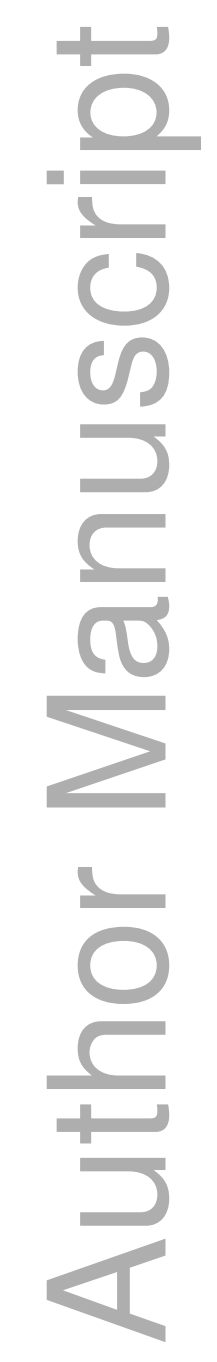

This article is protected by copyright. All rights reserved 


\section{University Library}

\section{- M M N E R VA A gateway to Melbourne's research publications}

Minerva Access is the Institutional Repository of The University of Melbourne

\section{Author/s:}

Pascoe, C;Duncan, C;Lamb, BW;Davis, NF;Lynch, TH;Murphy, DG;Lawrentschuk, N

Title:

Current management of radiation cystitis: a review and practical guide to clinical management

\section{Date:}

2019-04-01

\section{Citation:}

Pascoe, C., Duncan, C., Lamb, B. W., Davis, N. F., Lynch, T. H., Murphy, D. G. \& Lawrentschuk, N. (2019). Current management of radiation cystitis: a review and practical guide to clinical management. BJU INTERNATIONAL, 123 (4), pp.585-594. https:// doi.org/10.1111/bju. 14516.

Persistent Link:

http://hdl.handle.net/11343/284365 